WATER QUANTITY AND QUALITY DATA, SEPTEMBER-OCTOBER 1991, FOR SOURCE WATER TO THE LEAVENWORTH NATIONAL

FISH HATCHERY, WASHINGTON

By Robert E. Drzymkowski and Charles H. Swift, III

U.S. GEOLOGICAL SURVEY

Open-File Report 92-93

Prepared in cooperation with

U.S. FISH AND WILDLIFE SERVICE

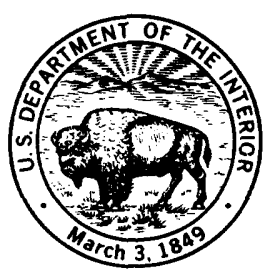




\section{U.S. DEPARTMENT OF THE INTERIOR}

MANUEL LUJAN, JR., Secretary

\section{U.S. GEOLOGICAL SURVEY}

Dallas L. Peck, Director

Any use of trade, product, or firm names is for descriptive purposes only and does not imply endorsement by the U.S. Government

For additional information

write to:

\section{District Chief}

U.S. Geological Survey

1201 Pacific Avenue - Suite 600

Tacoma, Washington 98402
Copies of this report may be purchased from:

U.S. Geological Survey

Books and Open-File Reports Section

Federal Center, Box 25425

Denver, Colorado 80225 


\section{CONTENTS}

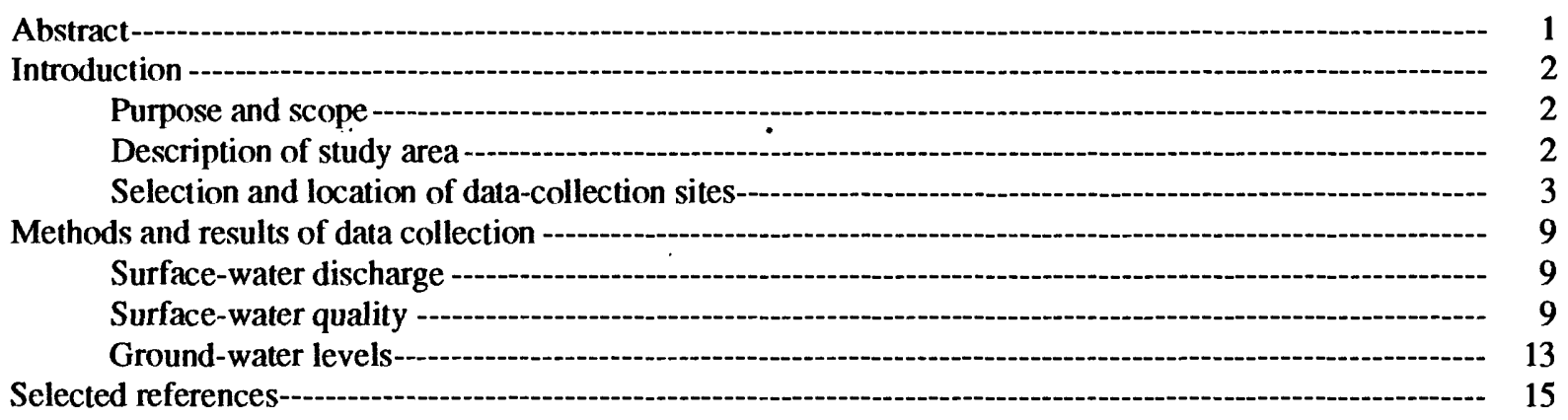

\section{ILLUSTRATIONS}

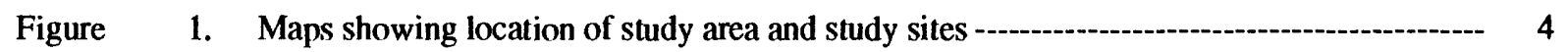

2. Diagram showing well-numbering system - -

3. Schematic showing the surface-water flow network and measurements of surface-water discharges, September 4 through October 10, 1991

\section{TABLES}

Table 1. Data-collection sites and types of data collected

2. Summations of discharges in the surface-water flow system

3. Water-quality measurements

4. Water-quality characteristics along stream cross sections

5. Measurements of depth to water at hatchery wells $3 \mathrm{~A}$ and 5 


\section{CONVERSION FACTORS AND VERTICAL DATUM}

Multiply

inch (in)

foot (ft)

yard (yd)

mile (mi)

square mile $\left(\mathrm{mi}^{2}\right)$

acre-foot (acre-ft)

foot per second ( $\mathrm{ft} / \mathrm{s})$

cubic foot per second $\left(\mathrm{ft}^{3} / \mathrm{s}\right)$
By

To Obtain
2.540

0.3048

0.9144

1.609

2.590

1,233

0.3048

0.02832 centimeter

meter

meter

kilometer

square kilometer

cubic meter

meter per second

cubic meter per second

Temperature: Air temperatures are given in degrees Fahrenheit $\left({ }^{\circ} \mathrm{F}\right)$, which can be converted to degrees Celsius $\left({ }^{\circ} \mathrm{C}\right)$ by the following equation:

$$
{ }^{\circ} \mathrm{C}=5 / 9\left({ }^{\circ} \mathrm{F}-32\right)
$$

Following convention, water temperatures are given in degrees Celsius, which can be converted to degrees Fahrenheit by the following equation:

$$
{ }^{\circ} \mathrm{F}=1.8\left({ }^{\circ} \mathrm{C}\right)+32
$$




\title{
WATER QUANTITY AND QUALITY DATA, SEPTEMBER-OCTOBER 1991, FOR SOURCE WATER TO THE LEAVENWORTH NATIONAL FISH HATCHERY, WASHINGTON
}

\author{
Robert E. Drzymkowski and Charles H. Swift, III
}

\begin{abstract}
Surface-water flow, ground-water levels, and water quality were measured at intervals from September 4 to October 10, 1991, in the vicinity of the Leavenworth National Fish Hatchery near Leavenworth, Washington. The measurements were made to establish baseline data for comparison with future information for streams that supply water to the hatchery, water flow in surface diversions, and water levels and quality of water from wells that supply water to the hatchery. Icicle Creek and its tributary, Snow Creek, are the main sources of water supply for the hatchery, but ground water is at times used to supplement the supply.

For five measurements made from September 4 to October 10, the discharges of Icicle Creek upstream from Snow Creek and upstream from the three diversions decreased from $195 \mathrm{ft}^{3} / \mathrm{s}$ (cubic feet per second) to $76 \mathrm{ft}^{3} / \mathrm{s}$. The five measured discharges of Snow Creek decreased from 37.5 to $31.8 \mathrm{ft}^{3} / \mathrm{s}$. The discharges diverted from Icicle Creek upstream from the hatchery ranged from 0 to $83.6 \mathrm{ft}^{3} / \mathrm{s}$ for the five measurements in each of the three diversions. Although inflow to the hatchery is not directly measurable, a summation accounting of the measurements of the inflow from the two streams minus the measured diversion flows indicates that the surface-water discharge available to the hatchery ranged from about 41.2 to $45.2 \mathrm{ft}^{3} / \mathrm{s}$. Water-quality characteristics of surface water as measured at four stream sites are generally good.

Ground-water levels in one of the two measured wells declined about 1 foot from September 6 through September 27, and then increased about 1 foot by October 10, 1991. Water temperatures were colder (7.5 degrees Celsius) in the shallower measured well than in the deeper measured well, which had temperatures similar to the surface-water sites. Dissolved solids, as indicated by specific conductance, were notably higher in ground water than in Icicle Creek. Other water-quality characteristics for ground water were generally similar to those for Icicle Creek, although the streptococci bacteria counts in water from wells were minimal and lower than in the surface waters.
\end{abstract}




\section{INTRODUCTION}

The U.S. Fish and Wildlife Service (USFWS) operates the Leavenworth National Fish Hatchery near Leavenworth, Washington, where about 2.5 million spring Chinook salmon and smaller numbers of steelhead trout are reared eảch year. The hatchery depends mainly on Icicle Creek for an adequate supply of good-quality fresh water. The surface-water supply is sometimes supplemented by ground water from local wells during the summer and fall when the flow or temperature of the stream is inadequate for hatchery operation. As an additional supplement, the USFWS can store up to 16,000 acre-ft of water in Snow and Nada Lakes. The stored water can be released through Snow Creek to enhance the flow in Icicle Creek during late summer and early fall.

There are three substantial diversions of water from Icicle Creek within 2 mi upstream from the fish hatchery. One of these is a combined diversion for the hatchery and Cascade Irrigation Canal.

The USFWS is concerned that water supplies available to the hatchery have diminished and water temperatures have increased in recent years. There is also concern that increased development and recreational use of the Icicle Creek drainage may adversely affect the quality and quantity of surface water and ground water available to the hatchery during low-flow periods. These changes could affect the productivity of the fish hatchery. Few data are known to exist that document these concerns and serve as a basis for comparison.

Consequently, the U.S. Geological Survey (USGS) agreed to collect baseline data for water quantity and quality that could be used by the USFWS for comparison with future water-supply conditions. The needed data includes flow and water quality in streams that supply water to the hatchery, water flow in surface diversions, and water levels and quality of water from wells that supply water to the hatchery. Baseline data for low-flow conditions were collected by USGS in cooperation with USFWS in September and October 1991.

\section{Purpose and Scope}

The purpose of this report is to present the water quantity and quality data that were collected at selected sites during September-October 1991 . The sites generally were selected to represent streamflow and surface-water diversions, as well as ground-water conditions in the immediate vicinity of the fish hatchery. One surface-water quality site was selected on Icicle Creek about $17 \mathrm{mi}$ upstream from the hatchery to obtain data from relatively pristine surface water.

\section{Description of Study Area}

The Icicle Creek study area includes a 2-mile reach of that stream upstream from the fish hatchery at river mile 3, and a single site on Icicle Creek upstream from Black Pine Creek at river mile 20. The study area is on the east slope of the Cascade Range and south of the town of Leavenworth, Washington. The drainage area of Icicle Creek at the mouth, near the hatchery, is $211 \mathrm{mi}^{2}$.

The Icicle Creek valley is generally deep and steep sided; mountains on either side rise to altitudes of more than $7,000 \mathrm{ft}$, including 9,426-ft Mt. Stuart along the southern basin boundary. The slopes are moderately to heavily forested. The hatchery is located on an alluvial floodplain less than 1 mi wide at an altitude of approximately $1,140 \mathrm{ft}$. The floodplain alluvium extends about $1 \mathrm{mi}$ upstream from the hatchery. Farther upstream, Icicle Creek is closely confined by valley walls and the amount of alluvium is minimal. 
Icicle Creek supplies water for the City of Leavenworth, two irrigation districts, and the hatchery. The basin is a popular recreation area that attracts more than 500,000 visitors during the summer season. In addition to an increasing influx of summer visitors, there is also an increase in construction of summer homes in the area upstream from the hatchery and year-round residences that use water in the general vicinity of the hatchery.

Mean annual air temperature at Leavenworth (U.S. Department of Commerce, 1989) is $48.8^{\circ} \mathrm{F}$ for a 56 -year period of record from 1934-1989; July is the warmest month (mean $70^{\circ} \mathrm{F}$ ) and January the coldest (mean $25^{\circ} \mathrm{F}$ ).

Mean annual precipitation at Leavenworth (U.S. Department of Commerce, 1989) is 25.7 inches for a 68-year period of record from 1922-1989. December has the largest mean monthly precipitation (4.6 inches), and most winter precipitation falls as snow. The lowest mean monthly precipitation is July ( 0.31 inches), and the mean monthly precipitation during the months of August, September, and October is $0.69,0.77$, and 1.8 inches, respectively.

The geology in the study area is a floodplain made up of Quaternary alluvium, a coarse gravel (Tabor and others, 1987). Logs of wells within the hatchery grounds indicate that the thickness of this alluvium is as much as $286 \mathrm{ft}$.

\section{Selection and Location of Data-Collection Sites}

Seven sites were chosen for measurements of surface-water flow during a period of low streamflows in September and October 1991 (fig. 1; table 1). Seven sites were required to define the quantity of surface water available to the diversions from Icicle and Snow Creeks, the water flow in the three diversions, the water supply to the hatchery from the Cascade Irrigation Canal, and the flow of Icicle Creek downstream from all diversions.

Site 2 on Icicle Creek was selected to quantify water flow at a point upstream from all diversions and most summer homes, and site 4 on Icicle Creek was selected to quantify water flow at a point downstream from those diversions and homes, but upstream from the hatchery. Site 2 is 0.4 mi upstream from Snow Creek at river mile 4.8 and is the site of a discontinued USGS streamflow data site (124580000), where 35 years of continuous streamflow record were collected from 1937-1971. Site 4 is located 1.3 river miles upstream from the hatchery.

Site 3 on Snow Creek was selected to quantify water flow in Snow Creek near its confluence with Icicle Creek. Site 3 is located where the Icicle-Peshastin Irrigation District Canal crosses over Snow Creek, 740 ft upstream from the mouth of Snow Creek.

Sites 5, 6, and 7 were selected to quantify the flow of water in each of the three diversions from Icicle Creek. Site 5 on the Icicle-Peshastin Irrigation District Canal is near the Snow Creek site, at the Snow Lakes trail footbridge. Site 6 on the City of Leavenworth diversion is inside the city water treatment plant at river mile 5.2. Site 7 on the common diversion for the fish hatchery and the Cascade Irrigation District is at river mile 4.5.

Site 8 on the Cascade Irrigation District Canal was selected to quantify the flow of water in the canal downstream from the hatchery diversion. Site 8 is at river mile 4.2, at a flume that splits Cascade Irrigation District water from the combined diversion with the fish hatchery. The difference between the discharges measured at sites 7 and 8 represents the amount of water diverted in a pipe to the hatchery. 


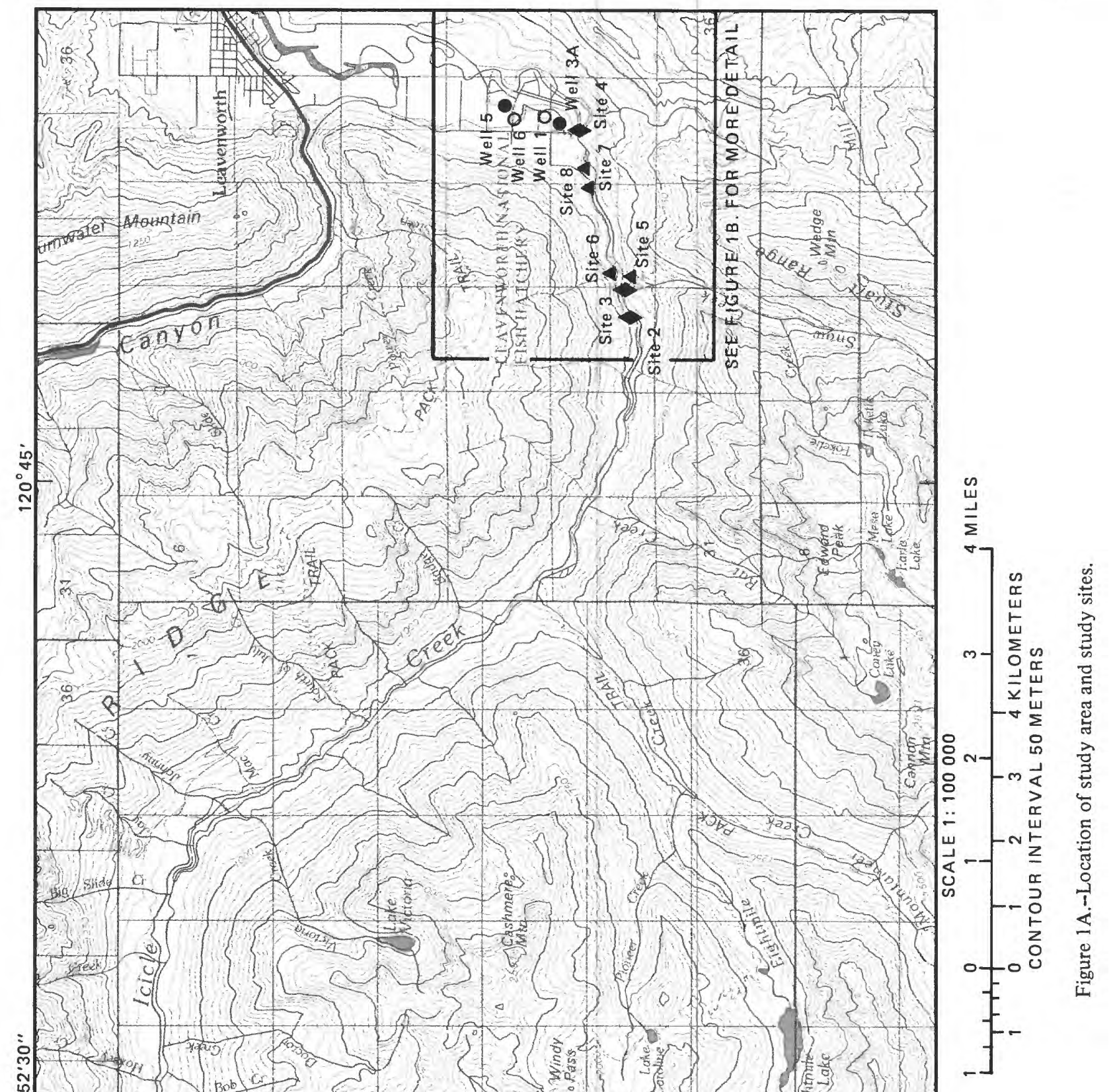




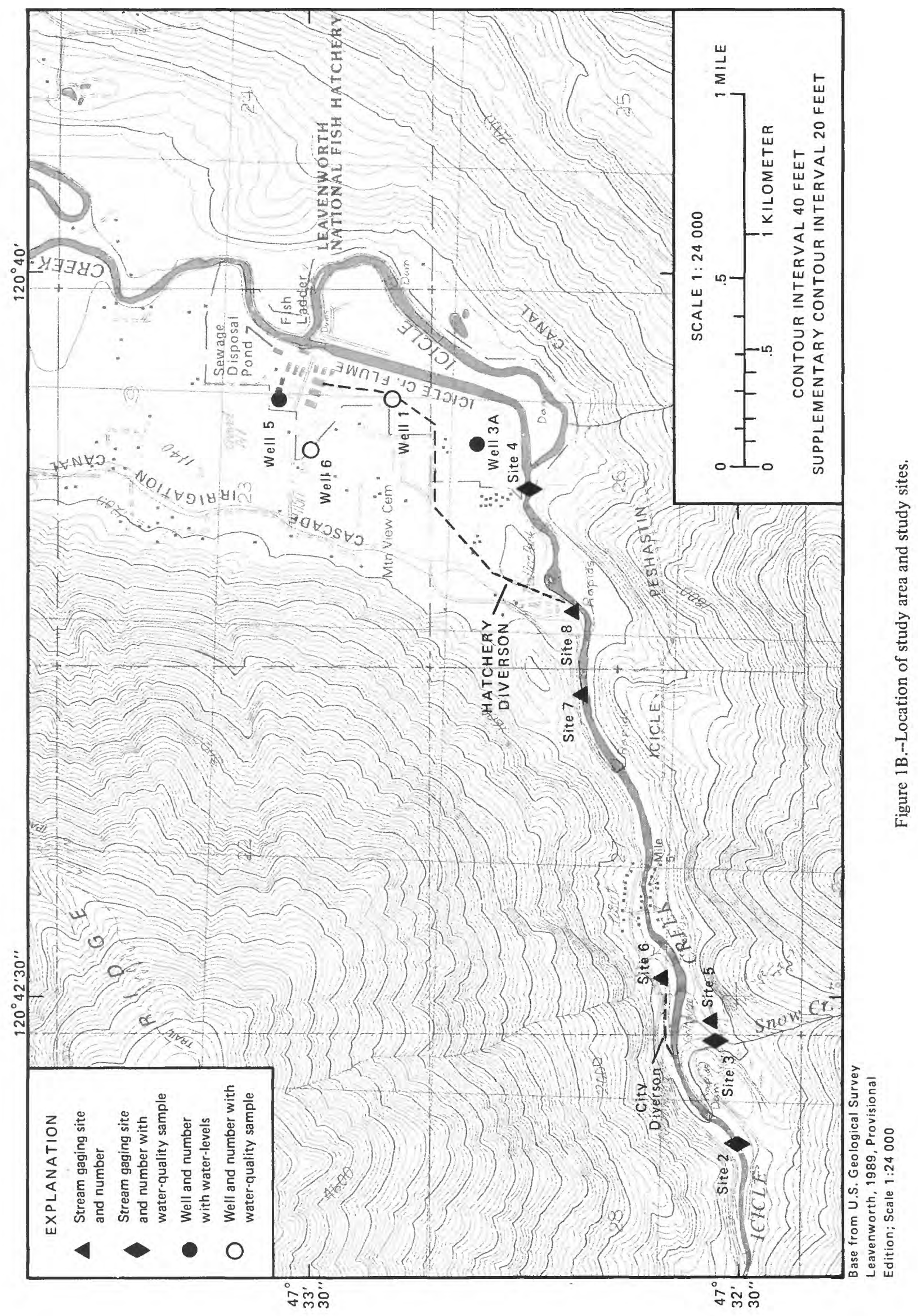


Surface-water quality was sampled at sites 2,3, and 4 and at site 1 on Icicle Creek. Site 1 is upstream from Black Pine Creek, upstream from the most upstream Icicle Creek campground accessible by driving. It was chosen to represent generally pristine surface water. Sites 2 and $3{ }^{\circ}$ were chosen to represent surface-water quality upstream from diversions and summer homes, and site 4 was chosen to represent the water quality upstream from the hatchery and downstream from summer homes.

Two of the hatchery's approximately ten wells were selected for measurements to document depth from land surface to water (fig. 1, table 1). Hatchery well number 5 is a few yards west of the hatchery complex. Hatchery well number $3 \mathrm{~A}$ is much closer to Icicle Creek, about $1 / 2 \mathrm{mi}$ south, or upstream from the hatchery. Well number 5 was not pumped until October 1, and well number $3 \mathrm{~A}$ was not pumped during the study period. These two wells were selected for measurement of ground-water levels because they were believed to represent generally static water levels at and upgradient from the hatchery during the time the wells were not being pumped.

Hatchery well numbers 1 and 6, one a shallow well and the other deep, were sampled for quality of ground water (fig. 1, table 1). Well number 1 is about $500 \mathrm{yd}$ south, or upstream from the hatchery, and is drilled to about $77 \mathrm{ft}$. Well number 6 is located about $800 \mathrm{ft}$ southwest of the hatchery and is drilled to a depth of $195 \mathrm{ft}$. Both wells were pumped for supplemental water supply to the hatchery on the days that the wells were sampled. These wells were selected for water-quality sampling because they were being purged by constant pumping and to determine any difference in water quality that could be associated with depth of well. 
Table 1.--Data collection sites and types of data collected

[x, data collected; --, no data collected]

Data Collected

\begin{tabular}{|c|c|c|c|c|c|}
\hline & & & & & \\
\hline $\begin{array}{l}\text { Site } \\
\text { number }\end{array}$ & $\begin{array}{l}\text { Site } \\
\text { name }\end{array}$ & $\begin{array}{l}\text { Latitude/ } \\
\text { longitude } \\
\text { identification } \\
\text { number }\end{array}$ & $\begin{array}{l}\text { Surface- } \\
\text { water } \\
\text { discharge }\end{array}$ & $\begin{array}{l}\text { Ground- } \\
\text { water } \\
\text { level }\end{array}$ & $\begin{array}{l}\text { Water } \\
\text { quality }\end{array}$ \\
\hline Gages & & & & & \\
\hline 1 & Icicle Creek above Black Pine Creek & 473648120564900 & -- & & $\mathbf{x}$ \\
\hline 2 & Icicle Creek above Snow Creek $\left(12458000^{1}\right)$ & 473228120430800 & $\mathbf{x}$ & & $\mathbf{x}$ \\
\hline 3 & Snow Creek near mouth & 473231120423900 & $\mathbf{x}$ & & $\mathbf{x}$ \\
\hline 4 & Icicle Creek above hatchery & 473259120404600 & $\mathrm{x}$ & & $\mathrm{x}$ \\
\hline 5 & Icicle-Peshastin Irrigation District & 473232120423700 & $\mathrm{x}$ & & -- \\
\hline 6 & City of Leavenworth & 473241120422700 & $\mathrm{x}$ & & -- \\
\hline 7 & LNFH-Cascade Irrigation District $^{2}$ & 473252120412800 & $\mathbf{x}$ & & -- \\
\hline 8 & Cascade Irrigation District & 473253120411000 & $\mathbf{x}$ & & - \\
\hline
\end{tabular}

Wells

1 Hatchery well $\left(24 \mathrm{~N} / 17 \mathrm{E}-23 \mathrm{Q} 01^{3}\right)$

473305120400001

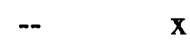

$3 \mathrm{~A}$ Hatchery well $\left(24 \mathrm{~N} / 17 \mathrm{E}-23 \mathrm{~K} 01^{3}\right)$

473330120403701

$\mathbf{X}$

473307120403600

$\mathbf{x}$

473336120402800

$\mathbf{X}$

$--$

5 Hatchery well $\left(24 \mathrm{~N} / 17 \mathrm{E}-26 \mathrm{~B} 02^{3}\right)$

$-$

6 Hatachery well (24N/17E-23K02 $\left.{ }^{3}\right)$

\footnotetext{
${ }^{1}$ USGS site number

${ }^{2}$ LNFH is Leavenworth National Fish Hatchery

${ }^{3}$ Local well number
} 


\section{Well-Numbering System}

In this report, in addition to hatchery well number, wells are also designated by local well numbers that indicate their location according to the rectangular-grid system for subdivision of public land (fig. 2, table 1). For example, in the local well number 24/17-23K01, the part before the hyphen indicates successively the township and range (T.24N., R.17 E.) north and east of the baseline and Willamette Meridian. Because all townships represented in this report are north of the baseline and east of the Willamette Meridian, the letters " $N$ " and " $E$ " are omitted in the local well number. The first number after the hyphen indicates the section (23) in which the well is located; the letter denotes the 40-acre subdivision of the section according to the diagram on figure 2 . The last number is the serial number of the well in the 40-acre subdivision. Thus, well 24/17-23K01 is in the NE 1/4 SE 1/4 sec. 23, T.24N, R.44 E., and is the first well in that tract to be recorded.

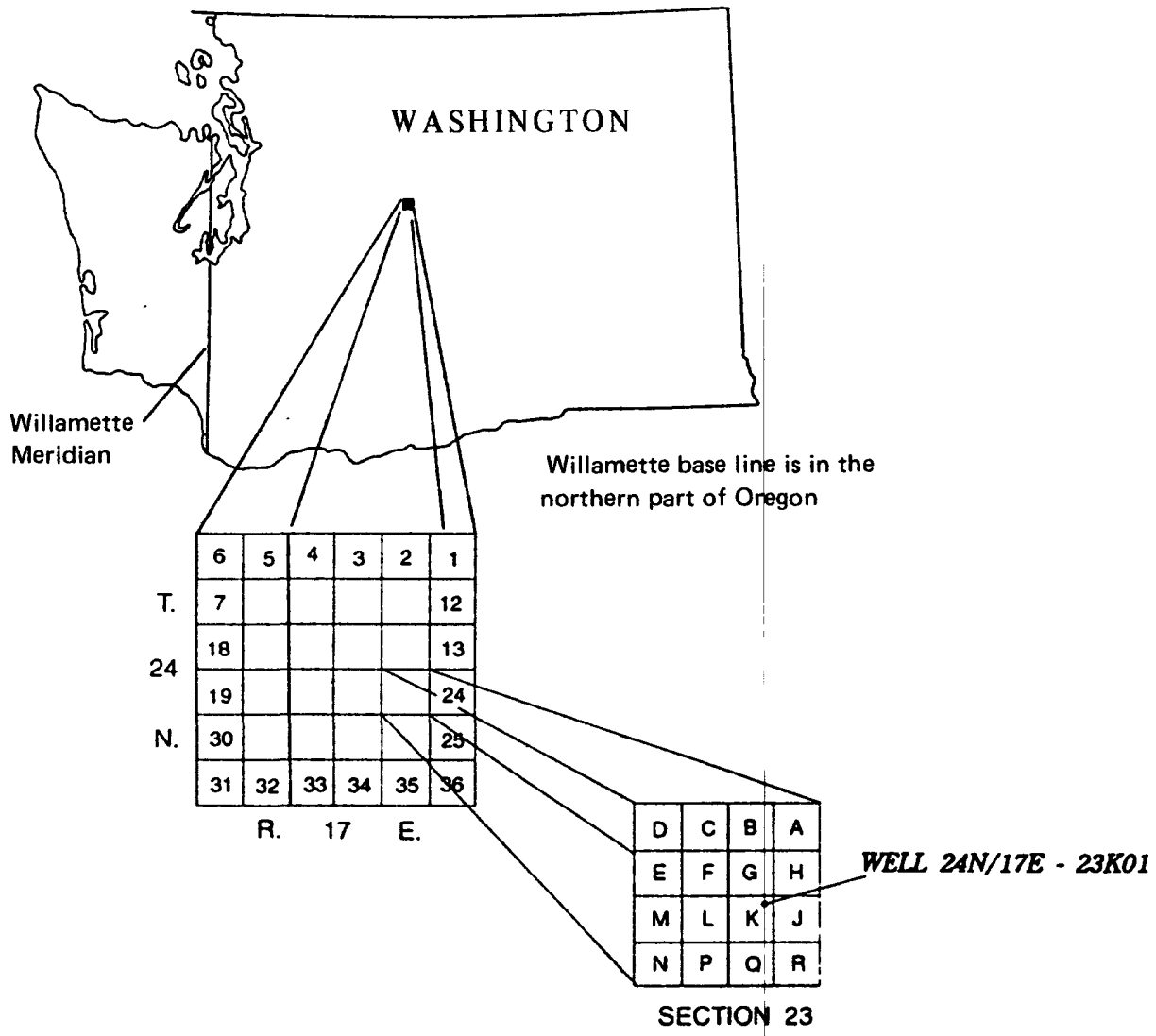

Figure 2.-Well-number system in Washington. 


\title{
METHODS AND RESULTS OF DATA COLLECTION
}

\author{
Surface-Water Discharge
}

Surface-water flows were determined by direct measurement using standard USGS velocity meters and methods described in "Measurement and Computation of Streamflow" (Rantz and others, 1982). Where possible, the measurements were made at channel locations that had good hydraulic conditions--straight reaches with parallel streamlines, uniform streambeds with a minimum of boulders, uniform flow free of eddies and excessive turbulence, velocities greater than $0.5 \mathrm{ft} / \mathrm{s}$, and depths greater than $0.5 \mathrm{ft}$. These ideal conditions did not always exist because of the rugged nature of this mountain stream, particularly at sites 2 and 3, where boulders and turbulence caused uneven velocity distribution.

Flows were measured at the seven surface-water sites (sites 2-8) on each of five visits during SeptemberOctober, 1991 (fig. 3). One to three days was required to make the measurements at all seven sites. The measured discharges ranged from zero on some dates at diversion sites 5,6 , and 8 to $195 \mathrm{ft}^{3} / \mathrm{s}$ at site 2 on September 5,1991 . Measured discharge at site 2 decreased from $195 \mathrm{ft}^{3} / \mathrm{s}$ on October 10 , while the measured discharge of site 3 decreased from $37.5 \mathrm{ft}^{3} / \mathrm{s}$ on September 5 to $31.8 \mathrm{ft}^{3} / \mathrm{s}$ on October 10. The discharges diverted from Icicle Creek upstream from the hatchery ranged from 0 to $83.6 \mathrm{ft}^{3} / \mathrm{s}$ for the five measurements in each of the three diversions.

For each visit to the sites in 1991, the flows measured at particular sites were added together to obtain either values of total streamflow available to the diversion network from Icicle and Snow Creek or the total water flow in the three diversions. In addition, flows at particular sites were subtracted to obtain either the residual difference between the total flows available and the total flow diverted, or the inflow to the hatchery. These calculated values are given in table 2. Calculated discharge available to the hatchery ranged from 41.2 to $45.2 \mathrm{ft}^{3} / \mathrm{s}$ during the study period. The residuals (total flow available minus total flow diverted) are directly comparable to the discharges measured at site 4 (Icicle Creek above hatchery) and serve as a measure of accuracy of measurements of flow at the sites. Notably, the measured discharges at site 4 are less than the residuals in September (as much as 14 percent less on September 4-6, 1991) and more than the residuals in October (as much as 11 percent more on October 10, 1991).

\section{Surface-Water Quality}

Samples of water from sites 1, 2, and 4 on Icicle Creek and site 3 on Snow Creek were collected on September 4 or 5 and September 26, 1991. All samples were collected, processed, and analyzed using standard USGS methods (Ward and others, 1990; Britton and Greeson, 1988; Fishman and Friedman, 1989). The surface-water-quality characteristics obtained from field measurements and laboratory analyses of the water sample at the four surface-water sites are listed in table 3.

Samples were collected using standard depth- and width-integrated methods. Suspended-sediment samples were collected with a DH-48 sampler. A DH-81 sampler was used for all other water constituents. Field measurements of temperature, specific conductance, and dissolved-oxygen concentration were made at four to five locations along the width of stream cross sections at the four sample sites on September 4 and 5, 1991, to determine uniformity of water quality along each cross section (table 4). The measured values varied little along the cross sections. 


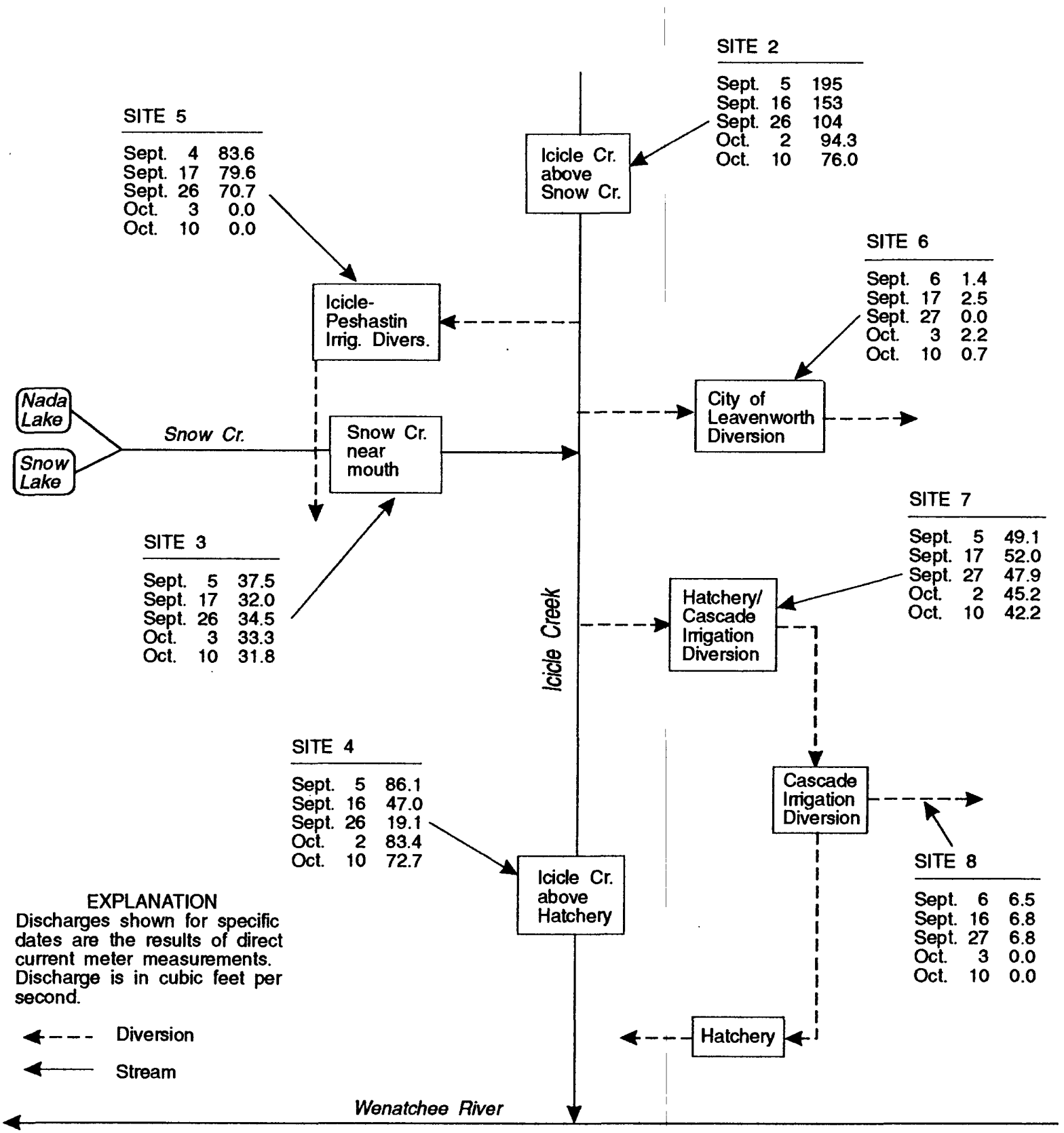

Figure 3.--Schematic showing the surface-water flow network and measurements of surface-water discharges, September 4 through October 10, 1991. 
Table 2..--Summations of discharges in the surface-water flow system

$\left[\mathrm{ft}^{3} / \mathrm{s}\right.$, cubic feet per second]

\begin{tabular}{|c|c|c|c|c|c|c|}
\hline \multicolumn{2}{|c|}{ Site 2 plus Site 3} & \multicolumn{2}{|c|}{ Site 5 plus Site 6 plus Site 7} & \multirow[b]{2}{*}{${\frac{\text { Residual }}{\left(\mathrm{ft}^{3} / \mathrm{s}\right)}}^{1}$} & \multicolumn{2}{|c|}{ Site 7 minus Site 8} \\
\hline $\begin{array}{l}\text { Date } \\
(1991)\end{array}$ & $\begin{array}{l}\text { Total } \\
\text { available } \\
\text { stream } \\
\text { discharge } \\
\left(\mathrm{ft}^{3} / \mathrm{s}\right)\end{array}$ & $\begin{array}{l}\text { Total } \\
\text { diverted } \\
\text { discharge } \\
\left(\mathrm{ft}^{3} / \mathbf{s}\right)\end{array}$ & $\begin{array}{l}\text { Percentage } \\
\text { of total } \\
\text { available } \\
\text { discharge } \\
\text { diverted }\end{array}$ & & Date & $\begin{array}{l}\text { Inflow to } \\
\text { hatchery } \\
\left(\mathrm{ft}^{3} / \mathrm{s}\right)\end{array}$ \\
\hline $09-04-09-06$ & 232 & 134 & 58 & 98 & 09-05 & 42.6 \\
\hline $09-16-09-17$ & 185 & 134 & 72 & 51 & $09-16$ & 45.2 \\
\hline $09-26-09-27$ & 138 & 119 & 86 & 19 & $09-27$ & 41.2 \\
\hline $10-02-10-03$ & 128 & 47.4 & 37 & 81 & $10-02$ & 45.2 \\
\hline $10-10$ & 108 & 42.9 & 40 & 65 & $10-10$ & 42.2 \\
\hline
\end{tabular}

${ }^{1}$ Residual is total available discharge minus total diverted discharge, and is comparable to measurements at site 4 .

The planned schedule for collecting water samples to determine the quality of water in the streams called for one sampling early in September. Samples for September 4 and 5 were measured on site to determine temperature, $\mathrm{pH}$, specific conductance, and dissolved-oxygen concentrations (table 3). Additional samples on September 4 and 5 were analyzed in the laboratory to determine constituents (table 3 ) commonly associated with septic wastes, which include nitrate, phosphate, chloride, boron, and MBAS (methylene-blue-active substances) and EDTA (ethylene diamine tetracetic acid), which are indicators of detergents. Samples for bacteria counts and temperature, specific conductance, and pH were collected on September 26-27, 1991 (table 3). No measurable suspended sediment was found in samples collected at the four surface-water sites on September 4-5.

Water temperature of Icicle Creek increased from $12.5^{\circ} \mathrm{C}$ at site 1 to $15.5^{\circ} \mathrm{C}$ at site 4 on September $4-5$ and from $9.0^{\circ} \mathrm{C}$ at site 1 to $14.0^{\circ} \mathrm{C}$ at site 4 on September 26-27. Specific conductance values were generally low and relatively uniform, ranging from 33-60 $\mu \mathrm{S} / \mathrm{cm}$ at all Icicle Creek sites during September 4-5 and September 26. Specific conductance at Snow Creek was $10 \mu \mathrm{S} / \mathrm{cm}$ for both samplings. Likewise, $\mathrm{pH}$ values were consistent, ranging from 7.7 to 7.9 standard units in Icicle Creek and 7.0 and 7.4 in Snow Creek. Dissolved-oxygen concentrations were also consistent, ranging from 9.6 to $9.7 \mathrm{mg} / \mathrm{L}$ in Icicle Creek and $10.7 \mathrm{mg} / \mathrm{L}$ in Snow Creek. The percent saturation of dissolved oxygen in Icicle and Snow Creeks ranged from 98 to 101 on September 4-5, 1991.

Fecal coliform bacteria counts were 3 colonies $/ 100 \mathrm{~mL}$ (colonies per 100 milliliters) or less of sample water and fecal streptococci counts ranged from 19 to 53 colonies per $100 \mathrm{~mL}$. None of the bacteria counts are considered to be high. Septic waste indicators were low, mostly at the lower limits of detection. 


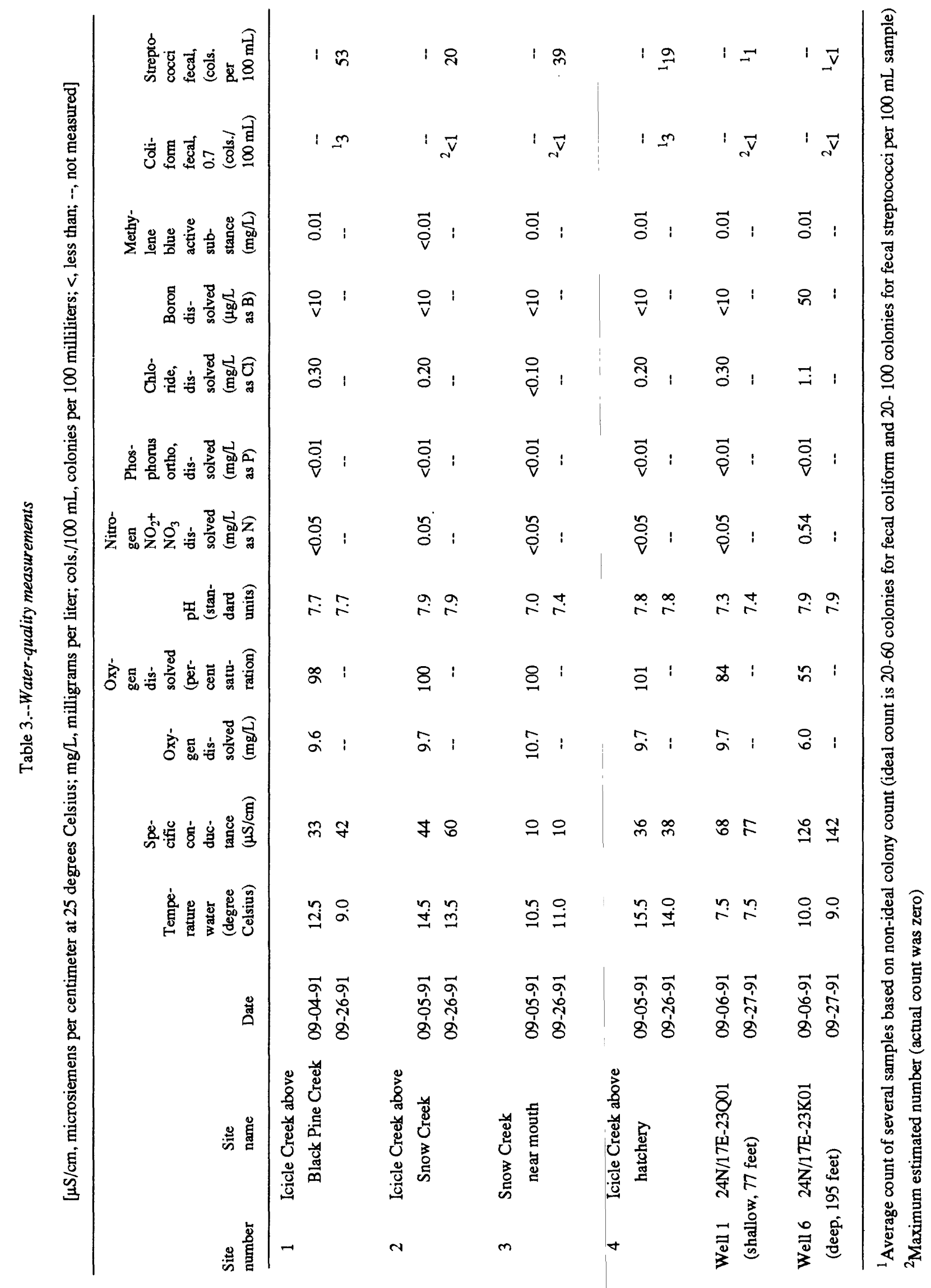


[Measurements of water-quality characteristics were spaced evenly along a stream cross section to represent equal discharge increments within the width of the cross section; $\mu \mathrm{Scm}$, microsiemens per centimeter at 25 degrees Celsius; $\mathrm{mg} / \mathrm{L}$, milligrams per liter]

\begin{tabular}{|c|c|c|c|c|c|c|}
\hline $\begin{array}{l}\text { Site } \\
\text { number }\end{array}$ & $\begin{array}{l}\text { Site } \\
\text { name }\end{array}$ & Date & $\begin{array}{l}\text { Temper- } \\
\text { ature } \\
\text { water } \\
\text { (degrees } \\
\text { Celsius) }\end{array}$ & $\begin{array}{l}\text { Specific } \\
\text { conduc- } \\
\text { tance } \\
(\mu \mathrm{S} / \mathrm{cm})\end{array}$ & $\begin{array}{l}\text { Oxygen, } \\
\text { dissolved } \\
(\mathrm{mg} / \mathrm{L})\end{array}$ & $\begin{array}{l}\text { Oxygen, } \\
\text { dissolved } \\
\text { (percent } \\
\text { satura- } \\
\text { tion) }\end{array}$ \\
\hline \multirow[t]{5}{*}{1} & \multirow[t]{5}{*}{ Icicle Creek above Black Pine Creek } & $09-04-91$ & 12.5 & 33 & 9.6 & 98 \\
\hline & & $09-04-91$ & 12.5 & 32 & 9.6 & 98 \\
\hline & & $09-04-91$ & 12.5 & 32 & 9.6 & 98 \\
\hline & & $09-04-91$ & 12.5 & 32 & 9.5 & 97 \\
\hline & & $09-04-91$ & 12.5 & 32 & 9.4 & 96 \\
\hline \multirow[t]{5}{*}{2} & \multirow[t]{5}{*}{ Icicle Creek above Snow Creek } & $09-05-91$ & 14.5 & 44 & 9.6 & 99 \\
\hline & & $09-05-91$ & 14.5 & 45 & 9.7 & 100 \\
\hline & & $09-05-91$ & 14.5 & 45 & 9.8 & 101 \\
\hline & & $09-05-91$ & 14.5 & 45 & 9.6 & 99 \\
\hline & & $09-05-91$ & 14.5 & 45 & 9.6 & 99 \\
\hline \multirow[t]{4}{*}{3} & \multirow[t]{4}{*}{ Snow Creek near mouth } & $09-05-91$ & 10.5 & 10 & 10.8 & 101 \\
\hline & & $09-05-91$ & 10.5 & 10 & 10.7 & 100 \\
\hline & & $09-05-91$ & 10.5 & 10 & 10.7 & 100 \\
\hline & & $09-05-91$ & 10.5 & 10 & 10.7 & 100 \\
\hline \multirow[t]{4}{*}{4} & \multirow[t]{4}{*}{ Icicle Creek above hatchery } & $09-05-91$ & 15.5 & 36 & 9.6 & 100 \\
\hline & & 09-05-91 & 15.5 & 36 & 9.7 & 101 \\
\hline & & $09-05-91$ & 15.5 & 36 & 9.7 & 101 \\
\hline & & $09-05-91$ & 15.5 & 36 & 9.7 & 102 \\
\hline
\end{tabular}

\section{Ground-Water Levels}

Depth from ground level to water was measured at wells $3 \mathrm{~A}$ and 5 during the period from September 6 through October 10, 1991 (table 5). Well 3A was not pumped during the study. Well number 5 had not been pumped for several weeks prior to the start of the study, but was pumped continuously after October 1 . For well number 5 , measurements after pumping started are not included in table 5. The measurements of depth to water indicate that water levels generally declined about $1 \mathrm{ft}$ from September 6 through September 27, and then increased about $1 \mathrm{ft}$ by October 10, 1991. The decline and increase in ground-water levels generally corresponds with a decline and increase in the flow of Icicle Creek at site 4. 
Table 5.--Measurements of depth to water at hatchery wells $3 A$ and 5

\begin{tabular}{|c|c|c|c|c|}
\hline $\begin{array}{l}\text { Site } \\
\text { number }\end{array}$ & $\begin{array}{l}\text { Land } \\
\text { surface } \\
\text { altitude } \\
\text { (feet) }\end{array}$ & $\begin{array}{l}\text { Well } \\
\text { depth } \\
\text { (feet) }\end{array}$ & $\begin{array}{l}\text { Date } \\
\text { water- } \\
\text { level } \\
\text { measured }\end{array}$ & $\begin{array}{l}\text { Depth } \\
\text { to } \\
\text { water } \\
\text { (feet) }\end{array}$ \\
\hline \multirow[t]{5}{*}{ Well 3A } & 1,140 & 92 & $09-06-91$ & 29.68 \\
\hline & & & $09-17-91$ & 30.68 \\
\hline & & & $09-27-91$ & 31.16 \\
\hline & & & $10-02-91$ & 30.05 \\
\hline & & & $10-10-91$ & 30.20 \\
\hline \multirow[t]{2}{*}{ Well 5} & 1,140 & 279 & $09-17-91$ & 22.84 \\
\hline & & & $09-27-91$ & 23.00 \\
\hline
\end{tabular}

The water-quality characteristics for ground water at wells no. 1 and 6 are given along with the surface-water-quality characteristics in table 3. These samples were obtained on September 6 and 27, 1991, from a faucet or spigot on the two wells while the wells were being pumped to supply supplemental water to the fish hatchery. Standard USGS methods (Britton and Greeson, 1988; Fishman and Friedman, 1989) were used for analyzing all samples. The ground-water samples were all analyzed for the same constituents as the surface-water samples.

Ground-water temperatures were lower $\left(7.5^{\circ} \mathrm{C}\right)$ on September 6 and 17 in the shallower well (well no. 1) than the deeper well. The deeper well (well no. 6), had temperatures $\left(9.0\right.$ to $\left.10.0^{\circ} \mathrm{C}\right)$ similar to the surface-water sites. Specific conductances were notably higher in the wells than in Icicle Creek, measuring 68 and $126 \mu \mathrm{S} / \mathrm{cm}$ on September 6, and 77 and $142 \mu \mathrm{S} / \mathrm{cm}$ on September 17, at wells no. 1 and 6, respectively. Dissolved-oxygen concentration and $\mathrm{pH}$ values in the wells were generally in the range of those observed in Icicle Creek, although dissolved-ox ygen concentration in the deeper well no. 6 was notably less $(6.0 \mathrm{mg} / \mathrm{L}$ and 55 percent saturation) than in Icicle Creek (9.6-9.7 mg/L and 98 to 101 percent saturation). Bacteria counts were 1 or fewer colonies per $100 \mathrm{mg} / \mathrm{L}$ of sample in both wells on September 27, 1991. 


\section{SELECTED REFERENCES}

Britton, L.J. and Greeson, P.E. (eds), 1988, Methods for collecting and analysis of aquatic biological and microbiological samples: U.S. Geological Survey Techniques of Water-Resources Investigations, Book 5, Chapter A4; Open-File Report 88-190, 685 p.

Fishman, M.J., and Friedman, L.C. (eds), 1989, Methods for determination of inorganic substances in water and fluvial sediments: U.S. Geological Survey Techniques of Water-Resources Investigations, Book 5, Chapter A1, $545 \mathrm{p}$.

Rantz, S.E., and others, 1982, Measurement and computation of streamflow: Volume 1, Measurement of stage and discharge: U.S. Geological Survey Water-Supply Paper 2175, 284 p.

Tabor, R.W., and others, 1987, Geologic map of the Chelan 30-minute by 60-minute quadrangle map, I-1661, scale 1:100,000.

U.S. Department of Commerce, 1989, Climatological data, 1989 annual summary: National Climate Data Center, v. 93 , no. 13 .

Ward, J.R., and others, 1990, Methods for collection and processing of surface-water and bed-material samples for physical and chemical analysis: U.S. Geological Survey Open-File Report 90-140, 71 p. 